\title{
Refugees as new Europeans, and the fragile line between crisis and solidarity
}

\section{Tatiana Thieme, Eszter Krasznai Kovacs and Kavita Ramakrishnan}

Abstract: This piece draws on recent research focused on the humanitarian politics of the refugee 'crisis' and its relationship with European futures. Our aim is three-fold: first, we contextualise the rise of right-wing populism and the politicisation of refugees in Europe. Second, we reflect on how state austerities place precarious refugees alongside marginalised European citizens, with under-explored consequences and tensions. Third, we point to the hopeful practices around the 'experimental humanitarianism' that we encountered across the four capital cities in which we conducted research. The paper highlights the limitations of state-centric provisioning and the potential pathways that existing experiments of solidarity can build on the margins of European cities. These are often unseen or off-grid nodes of hope set against a backdrop of generalised European political malaise.

Keywords: Refugees as New Europeans, crisis, hope, solidarity, cities.

Authors: Tatiana Thieme is an Associate Professor in Human Geography at University College London. Her research focuses on informal work, 'hustle economies' and everyday coping strategies in precarious urban environments, with a regional focus on African and European cities. Together with Eszter Kovacs and Kavita Ramakrishnan, she is the recipient of a British Academy Tackling the UK's International Challenges Award to complete a project titled 'Temporary Migrants or New European Citizens? Geographies of Integration and Response Between "Camps" and the City".

t.thieme@ucl.ac.uk

Eszter Krasznai Kovacs is currently a Leverhulme Early Career Research Fellow at the University of Cambridge and research fellow at the Budapest University of Corvinus. Her research focuses on how people and NGOs navigate European rules and systems of governance in post-socialist countries.

Kavita Ramakrishnan is a Lecturer in Geography and International Development at the University of East Anglia. Her research interests lie in issues around eviction and resettlement, informal housing and everyday experiences of marginalisation in south Asian and European cities.

(C) The author(s) 2020. This is an open access article licensed under a

Creative Commons Attribution-NonCommercial-NoDerivs 4.0 Unported License 


\section{THE CHALLENGE TO EUROPEAN COHESION}

Over the past few decades, immigration has been a contentious issue in several EU member states, whether arrivals are economic migrants or asylum seekers from wartorn states. Technically, 'asylum seekers' are people who have lodged a claim for asylum under the Geneva Convention, while 'refugees' are asylum seekers whose claim has been accepted. This piece will treat both groups as one. Popular discourse uses 'refugees' and 'asylum seekers' interchangeably and also conflates them with 'migrants' arriving on some other basis - for example, Eastern Europeans arriving in Western European countries to seek work. In every destination country the arrival of large numbers of people has given rise to concern from the public. While most EU member states still officially maintain their obligation under the Geneva Convention to provide a safe haven for refugees, the trend of policy has been to restrict the numbers of arrivals as far as possible and to contain those who do arrive in the EU to the member state of first entry.

Given that most refugee arrivals since 2015 have been by sea, the Mediterranean EU members have been on the front line of reception, and this has led to tensions and resentment between states. Mediterreanean states are expected to accommodate new arrivals rather than allow them to travel on to member states further north. The refugee issue has come to assume huge importance for pan-continental political agenda and divided Europe into 'frontline' and 'non-frontline' states. On the one side, the outcomes of recent elections in certain member states, such as Hungary, Italy, Poland and Austria, have promoted calls for the redesign of the EU as a political project, reaffirming nationalism and closed borders to minimise migrant numbers. On the other side, the numbers drowning in the Mediterranean and the desperate conditions of those rescued from the sea have prompted a humanitarian outcry. Both in sea rescue missions and in assistance to refugees in Europe's cities, a multitude of voluntary organisations have pushed back against various governments' failure or refusal to cater to refugees' needs.

In 2017, concerned with the humanitarian politics of the refugee 'crisis' and its relationship with European futures, we embarked on a multi-sited research project, 'Temporary Migrants or New European Citizens? Geographies of Integration and Response Between "Camps" and the City'. ${ }^{1}$ The project examined the different representations and post-2015 politics of refugee arrival across Europe by focusing on four capital cities - Athens, Budapest, Berlin and Paris - where state-led and experimental civil society humanitarian and political responses converged (and at times clashed),

${ }^{1}$ Further information can be found on the project website (http://www.camps2cities.com/) and through the British Academy (https://www.thebritishacademy.ac.uk/projects/uk-international-challenges-16temporary-migrants-or-new-european-citizens). 
shaping diverse scales of care on the one hand, as well as denials of refugee status and rights and outright expulsions on the other.

Except for Athens, none of the aforementioned capitals may be considered a first point of entry, as they are physically far away from any actual borders. This reflects the unequal challenge borne by Southern and Eastern European states, where distances sow the seeds for repressive responses and political imaginaries that emphasise fear. Over time, the 'refugee crisis' transitioned from emergency mode to a phase of adjustment and integration, with diverse outcomes and approaches. Substantial resources have been expended to deny the right to lodge an asylum claim (Budapest), while a constellation of formal and informal humanitarian actors try to meet immediate and longer term needs for refugees in cities where the shortage of housing and work is already acute for local citizens (Athens, Berlin and Paris).

These political turbulences have given rise to the unfortunate shared experience across Europe of the criminalisation of humanitarian provision by civil society groups and individuals, and the normalisation of discourse on the (negative) impact of refugees on European societies. Below we contend that the refugee crisis is merely a symptom of a deeper political crisis in Europe. Firstly, we examine the politicisation of refugees by rising right-wing populism. Secondly, we reflect on how state austerities place precarious refugees alongside marginalised European citizens. Thirdly, we explore the potential of the 'experimental humanitarianism' that we encountered in each capital city. We thus aim to highlight the limitations of state-centric provisioning and the potential pathways that existing experiments of solidarity create on the margins of European cities. These are often unseen or off-grid nodes of hope, against a backdrop of seemingly unhopeful events and rhetoric at the larger scale.

\section{THE POLITICISATION OF REFUGEES}

Emmanuel Macron started his presidency in 2017 with claims to balance 'humanity and firmness', reaffirming the strict distinction between economic (undeserving) migrants and political (deserving) refugees. Angela Merkel in 2015 assured Germans and the rest of Europe that 'we can do this' (Wir schaffen das!), initiating an opendoor policy to refugees during that year's 'peak' refugee 'crisis'. While Angela Merkel's position on refugees may have spoken of welcome in Europe, her expansive approach was not shared throughout Europe and was criticised as undemocratic, especially by the frontline states as well as within Germany. This also reflects the different pasts of Western European countries - 'guest workers' in Germany's case-which are not narratives shared by Southeastern European states.

The most egregious forms of refugee politicisation undertaken by a member state 
occurred in Hungary. During 2018, the Hungarian state spent over 200 million euros on a countrywide advertising campaign designed specifically to demonise refugees and normalise xenophobic sentiment. The campaign culminated in Viktor Orbán's reelection in April 2018. Meanwhile the Hungarian move to the political right has been matched by the rise of the Alternative for Germany Party, the (brief) success of Sebastian Kurz in Austria, Matteo Salvini in Italy and the political rhetoric emerging from Poland's Law and Justice Party. Active distortions of what is to be feared from refugees entering Europe have been matched by increasingly punitive asylum and migration laws. Furthermore, it has become clear that refugee crises in Europe are inextricably tied to austerity politics in the aftermath of the 2008 global financial crisis, contested identity politics and already-extant, widespread and overlapping precarities amongst diverse vulnerable groups. These crises serve also to fuel resentment between different member states which see themselves as disproportionately burdened.

\section{REFUGEE AND CITIZEN PRECARITY AND PERIPHERALITY}

Across Paris, Berlin, Athens and Budapest, the political rhetoric on display at the national and EU levels conflicts with the realities of having to provide for refugees and asylum claimants today, pressures and demands largely borne by local governments. This is exemplified by Hungary where, during 2018, the national government denied taking in any refugees, while at the same time Budapest City Council actively ran a 'Refugee Point' financed by the EU to welcome refugees granted asylum in Hungary. The Refugee Point registered, on average, three individuals per day, while being prohibited to advertise its own existence.

Although the Hungarian case is an exceptional one, other European cities are also unsure about how to acknowledge and coordinate the constellation of actors who work at different scales to ensure emergency and long-term provision. Polarising debates and finger-pointing persist regarding the respective roles of municipalities, national governments and the EU, against the backdrop of protracted austerity measures that continue to elicit contested responses a decade after the 2008 global financial crash. Since November 2018, the 'gilets jaunes' movement in France has highlighted the number of European citizens in precarity more generally, from the increasing number of those dependent on government aid and living on the streets, to those dispossessed by the uneven effects of globalisation. Citizen and refugee precarity and peripherality reveal geographic and situational 'overlaps' and commonalities.

These persistent overlaps between refugees and European citizens are frequently lived as one where they must 'compete' for resources. Interviews in homeless shelters in Athens and Budapest revealed that local housing for citizens was at an all-time low 
amidst exceptionally high demand. This contrasted with the perception of generous European financing available for refugee housing. In Athens, Budapest and Berlin, rates of public payments to refugees are often quoted as higher than those to citizens. These lopsided privileges are triggers for resentment, frequently exploited by right-leaning media, as well as the source of tensions between settled migrants and more recent refugees.

Porte de La Chapelle, a de facto refugee hub in northern Paris, was already an area known for its deprivation, with widespread drug use and homelessness. It is now fairly common for young, vulnerable refugees in the area to fall victim to drug gangs and addiction. Volunteers who serve meals in this area find that local, precarious French citizens also need their services - and thus often end up casting a wider net over both refugee and vulnerable local populations, demonstrating how austerity politics bring together these varied groups and raising questions about who the state should prioritise with limited resources. So, the 'timing' of arrivals from the Middle East and Africa has coincided with a moment of otherwise already extant, widespread economic and democratic crisis.

\section{COUNTER-MOVEMENTS: EXPERIMENTAL HUMANITARIANISM}

In each city, civil society actors have risen to fill gaps in provisioning for refugees, as the state either cannot or will not fulfil its remit. These models and initiatives all share core themes around experimentation, ranging from a number of dedicated individuals rising early to brew tea and coffee for young asylum claimants with nowhere to live, to highly coordinated and networked civil society organisation (CSO) arrangements branching out into new forms of care. We have seen sophisticated systems of food and clothing delivery develop on the streets of Paris, for instance, where volunteers and grassroots collectives are able to target vulnerable individuals and spread accurate information about ever-changing legal procedures. CSOs are often the first to recognise and adapt their programming. Thus, in Athens, CSOs have come to recognise that livelihood and entrepreneurship programmes are critical to refugee integration.

Civil society actors that provide services to refugees face key challenges. Across Europe, a range of political, legal and financial changes have seriously affected the operational capacities of CSOs, from the established NGOs (nongovernmental organisations) to more ad hoc neighbourhood collectives. Often, establishing longer term programmes is beyond the capacity of 'frontline' CSOs, and 'seed-funding' philanthropists are increasingly behind many initiatives. The challenges facing civil society amount to a (constructed and fuelled) 'crisis in legitimacy' in Greece and Hungary in particular, as these groups are seen to be funded by 'external', monied 
'liberal' philanthropists working against the interests of the nation-states in question. While these concerns raise fundamental questions about the role of civil society, they also highlight the emergence of a new mode of governance and financial operations between CSOs and the intranational EU sphere.

In some cases, experimentation also extends to cities in terms of new ways of provisioning. For example, municipal/civil society coordination efforts address limitations to refugee integration and implement new ways of connecting volunteer and NGO initiatives to those of the state. In Athens, municipal experimentation covers the ways in which such initiatives are financed, an outcome of state bankruptcy and deep indebtedness that leaves little to no money for new initiatives. In response, the Athens Partnership was established as a private-public partnership with the Stavros Niarchos Foundation to give rise to the Athens Coordination Centre for Migrants and Refugees, with the explicit aim of bringing together all CSOs and community groups that serve refugees across five core themes, from immediate care to entrepreneurial development. This model also sees the sharing of tasks between local government agencies and their civil counterparts within the group's own development and management.

In Paris, street-level civil society mobilisation has been vital in the immediate term, but has raised questions about the inevitably palliative nature of emergency modes, leading to volunteer burnout along with continual evictions of both humanitarian hubs and makeshift migrant settlements. Nevertheless, it has also provided crucial solidarities and alternative organisational experiments, operating outside formal humanitarian spaces but not always cut off from municipal support. Since August 2018, the daily distribution of breakfast by Migrants Solidarités Wilson, that had taken place for two years near Porte de la Chapelle in solidarity with at-risk migrants (and rough sleepers), has been increasingly recognised by city officials as a vital provision node in one of the most precarious neighbourhoods of Paris. The City Council, along with the Salvation Army, have now taken over the daily operations, while continuing to liaise with the self-appointed social workers who have accrued local knowledge and an understanding of the rapidly changing (and often seasonal) street politics amongst refugees and volunteers.

In Berlin, the focus of organisations, such as Diakoniewerk Simeon, supporting refugee 'social integration' has turned to career counselling and mentorship programmes for young refugees, who receive significant state support until the age of 18 when it is suddenly cut off as they transition (in age terms at least) to adulthood. Increasingly, more settled Syrian refugees have become social workers supporting at-risk youth who often end up on the streets as prime targets for underground gang activities. These examples do not point to obvious policy fixes, but rather to meaningful encounters and alternative social economies in the making. 


\section{SCALES OF HOPE AND EXPERIMENTATION}

This current moment throws into sharp relief the confluence of austerity politics, a decade of uneven recovery and investment following the global financial crisis, and the contested debates regarding the largest refugee crisis to affect Europe since the Second World War. As the humanitarian emergency phase of the refugee influx seems to have diminished with sharply declining numbers of new arrivals into Europe, the real work is only starting, at a time when significant labour-related politics and rising precarity are being hotly contested.

European cities have become the stage on which alternative humanitarian, economic and political experiments have taken place in the face of persistent uncertainty, unrest and precarity. While a constellation of actors has been implicated in debates concerning the humanitarian, labour and political futures of the EU, civil society actors have mobilised outside traditional institutional structures to create alternative economic and humanitarian models, often at neighbourhood scales.

The next step will be to follow the trails of these alternative economic experiments that appear ephemeral and underground, but also point the way to potentially pragmatic solutions and prefigurative politics. The ways in which people survive, create social ties and experiment with alternative economic ideas indicate emerging forms of solidarity and social economies that are street-born and street-led, and are eliciting the attention of diverse actors at the nexus of social entrepreneurship and activism, circular economies and solidarity movements. In the period ahead, it will be crucial to take seriously the fractured politics of outrage against rising inequality and the political elite classes, but also to keep a hopeful eye on the progressive counter-currents to the rise of repressive policies and attitudes towards (all) precarious groups, and work to resolve the tensions and resentments between EU member states to build humanitarian solidarity.

To cite the article: Tatiana Thieme, Eszter Kovacs and Kavita Ramakrishnan (2020), 'Refugees as new Europeans, and the fragile line between crisis and solidarity', Journal of the British Academy, 8(s1): 19-25.

DOI https://doi.org/10.5871/jba/008s1.019

Journal of the British Academy (ISSN 2052-7217) is published by

The British Academy, 10-11 Carlton House Terrace, London, SW1Y 5AH www.thebritishacademy.ac.uk 
